\title{
Compliance - przedmiot, zakres i środki ochrony
}

\author{
Compliance - Its Purpose, Scope, and Protection Instruments
}

\author{
Andrzej Janik \\ Kolegium Gospodarki Światowej, Szkoła Główna Handlowa w Warszawie \\ ORCID: https://www.orcid.org/0000-0003-1449-2555• ajanik1@sgh.waw.pl \\ Zgłoszono: 20.02.2020; zrecenzowano: 7.04.2020; zaakceptowano do druku: 17.04.2020
}

\begin{abstract}
Streszczenie: Compliance w powszechnej praktyce oznacza działalność zgodną z prawem i etyką. Dotyczy to działalności gospodarczej - zwłaszcza regulowanej (nadzorowanej) - ale również sektora publicznego. W strukturach wewnętrznych organizacji pojawiają się specjalne komórki nadzoru nad zgodnością. Ich istnienie jest obowiązkowe - w branżach nadzorowanych, w szczególności w obszarze usług finansowych - albo opcjonalne, jeśli uzasadnia to skala i znaczenie organizacji. Przepisane prawem zasady organizacji i funkcjonowania compliance w podmiotach nadzorowanych stanowią niewątpliwie wzór dla przedsiębiorstw z innych branż. Instrumenty regulacji compliance mają głównie charakter proceduralny. Przedmiotem ochrony regulacji nie jest sama zgodność (compliance) jako taka. Są nim dobra i wartości podstawowe - środowisko naturalne, równość, godność, solidarność. Ta ostatnia pojawia się zwłaszcza w kontekście rozpowszechnionych - i nagannych - praktyk unikania opodatkowania poprzez księgową alokację aktywów do tzw. rajów podatkowych. Korzystanie z zasobów i infrastruktury kraju prowadzenia działalności, ponoszącego koszty ich powstania i utrzymania, nie towarzyszą żadne, albo tylko szczątkowe, daniny na jego rzecz. Punktem wyjścia compliance były głośne przypadki ujawnione poprzez tzw. sygnalizację (whistleblowing), która dała początek compliance jako problemowi organizacji przedsiębiorstwa. Funkcja ta wymaga określonych gwarancji chroniących osobę sygnalisty (demaskatora), jak i osobę, wobec której formułowane są zarzuty. W szerszym kontekście compliance stała się częścią składową "ładu korporacyjnego" lub "dobrych praktyk."
\end{abstract}

Słowa kluczowe: compliance, regulacja, unikanie opodatkowania, whistleblowing, dobre praktyki, ład korporacyjny

Abstract: In common practice, compliance means acting in accordance with the law and ethics. This applies to business activities, especially the regulated (supervised) ones, but also to the public sector. In both areas, there appear to be special units in the internal structure of the organisation, dedicated to compliance supervision. They are either mandatory - in supervised industries, this refers in particular to financial services - or voluntary, if the scale and the significance of the organisation justify their existence. The legally prescribed rules on the organisation and operation of compliance in supervised entities, undoubtedly set the pattern for firms in other branches. The regulatory instruments of compliance are mainly of a procedural nature. The subject-matter of the protection is not compliance itself, but rather primary goods and values such as the environment, equality, dignity, solidarity. The last one comes to the fore, especially, in the context of the widely spread - and reprehensible - tax avoidance practices through allocation of assets to the so-called tax paradises. Making use of the resources and infrastructure of the country where business operations are conducted, is accompanied by none, or by hardly any levies for its benefit. The starting point for compliance was a set of high-profile cases, disclosed through what is popularly known as "whistleblowing", which fuelled the idea of introducing compliance as a primary issue for corporate organisations. That function requires some special guarantees, protecting the "whistle blower", and 
the person that is being incriminated. In the broader context, compliance has become a component part of corporate governance, or of its softer form, "good practices".

Keywords: compliance, regulation, tax avoidance, whistleblowing, good practices, corporate governance

\section{Funkcja compliance}

Istota compliance nie budzi wątpliwości. Stanowiąc wyraz społecznej odpowiedzialności biznesu, compliance obejmuje wszelkie środki i metody służące zapewnieniu przestrzegania reguł postępowania, w tym również w sferze wykraczającej poza prawo stanowione (zasady etyczne oraz tzw. dobre obyczaje czy dobre praktyki). Jest to agenda, która ma na celu identyfikację i zminimalizowanie ryzyka braku zgodności działań podmiotu (firmy) z przepisami prawa, regulacjami wewnętrznymi i standardami postępowania.

Funkcja compliance bywa wykonywana łącznie $z$ inną, np. doradztwem prawnym, kontrolą wewnętrzną lub audytem wewnętrznym. Z racji jednak możliwego konfliktu interesów, jak również specyfiki compliance, kompetencje w tym zakresie powierza się coraz częściej wyspecjalizowanym stanowiskom, a w większych przedsiębiorstwach - wieloosobowym komórkom sprawującym wewnętrzny nadzór zgodności. Podobne motywy pojawiają się również w funkcjonowaniu sfery publicznej - urzędów, agencji państwowych i samorządowych oraz uczelni wyższych. W ramach ich struktury wewnętrznej powołuje się rzeczników i komisje etyki, których pozycja i funkcje są odpowiednikiem komórek compliance w biznesie. Tak w przypadku przedsiębiorstw, jak i osób prawa publicznego chodzi o to, by ich zadania i cele były realizowane w zgodzie z zasadami etyki, które specyfikuje się na potrzeby danej jednostki organizacyjnej (przedsiębiorstwa, uczelni) w postaci kodeksów etyki. Kodeksy takie wprowadzono w wielu polskich bankach, np. w Banku Zachodnim WBK SA, Banku Gospodarki Żywnościowej (obecnie BNP
Paribas), jak również w Lyreco oraz w Szkole Głównej Handlowej.

Znaczenie compliance sprawiło, że stała się dyscypliną uprawnianą na poziomie akademickim. Poza względami natury naukowej spowodowały to potrzeby dydaktyki. Te z kolei zostały wykreowane przez popyt na specjalistów compliance zgłaszany przez coraz to nowe branże przedsiębiorstw, jak również wzrastające budżety wyspecjalizowanych komórek compliance.

Compliance jest w pierwszym rzędzie konsekwencją procesów regulacyjnych. Regulator-nadzorca zewnętrzny jest zainteresowany tym - i z racji swojej pozycji jest w stanie o to zadbać - żeby podmioty nadzorowane same monitorowały swoja działalność z punktu widzenia jej zgodności z prawem i zasadami etyki. Podmioty te w swojej strukturze wewnętrznej powinny posiadać nadzór zgodności (compliance) choćby dlatego, by sprawować bieżącą kontrolę wykonania instrumentów nadzoru zewnętrznego (zalecenia, stanowiska etc.). Nadzorowi zewnętrznemu regulatora towarzyszy wewnętrzny nadzór zgodności realizowany przez komórkę compliance. Nadzór compliance czuwa nie tylko nad implementacją i stosowaniem nadzoru zewnętrznego, lecz także obejmuje swoim zasięgiem cały obszar potencjalnych naruszeń prawa i etyki.

Procesy regulacyjne rozpoczęły się i są najbardziej zaawansowane w branży finansowej - wrażliwej z punktu widzenia bezpieczeństwa środków deponentów i inwestorów. Krajowy nadzór zewnętrzny w sferze finansów, sprawowany w Polsce przez Komisję Nadzoru Finansowego (KNF), stanowi część systemu nadzoru w skali międzynarodowej. Europejski Urząd Nadzoru Giełd i Papierów Wartościowych (European Securities and 
Markets Authority, ESMA) jako część Europejskiego Systemu Nadzoru Finansowego (ESNF) wydaje wytyczne i zalecenia skierowane do właściwych organów lub uczestników rynku finansowego, w szczególności do podmiotów nadzorowanych. Właściwe krajowe organy nadzoru i uczestnicy rynku finansowego mają obowiązek dołożenia wszelkich starań, aby zastosować się do tych wytycznych i zaleceń - w ciągu 2 miesięcy od wydania wytycznej lub zalecenia ich adresat powinien potwierdzić, czy stosuje się lub zamierza zastosować się do danej wytycznej lub zalecenia, względnie uzasadnić odmowę według zasady comply or explain, tzn. stosuj lub wyjaśnij, dlaczego nie stosujesz, albo nie zamierzasz się stosować (Eleryk, Piskorz-Szpytka i Szpytka 2019, 62). Procesy regulacyjne postępują, obejmując kolejne sektory gospodarki, w szczególności przemysł farmaceutyczny, telekomunikację, energetykę i transport.

Sfera ochrony compliance jest szersza niż tylko nabywcy (klienci) dóbr i usług świadczonych przez dany podmiot. Zasięg dóbr lub interesów chronionych przez compliance jest identyfikowany ryzykami, których neutralizacji ma służyć efektywna realizacja obowiązków w zakresie compliance. Najszerszy krąg ochrony wyznaczają ryzyka ekologiczne, których źródła pojawiają się praktycznie w każdej sferze aktywności biznesowej, łącznie z reklamą i marketingiem. Przykładowo, intensywne akcje promowania sprzedaży detalicznej określonych towarów mogą popaść w kolizję z deklarowanym celem ekologicznym. Kampania reklamowa, jako taka oczywiście, nie jest deliktem compliance. Może nim być natomiast niekoherentna, dwulicowa polityka rynkowa: przedstawianie się publiczności jako ekofirma, dotrzymująca najwyższych standardów w zakresie ochrony środowiska, a jednocześnie prowadzenie agresywnej promocji sprzedaży wyrobów dewastujących środowisko, np. wyrobów z bawełny, której uprawa i produkcja jest bardzo wodochłonna - do produkcji jednego t-shirta trzeba zużyć 2,6 tony, a do pary dżinsów 7,5 tony wody (Solska 2020, 40) .

Okoliczność, w czyim interesie realizowana jest compliance i czyjej ochronie służy, uzmysławia znaczenie tych przedsięwzięć. Ich funkcja ochronna obejmuje:

- sam podmiot (jednostkę organizacyjną) narażony na rozmaite ryzyka związane z prowadzoną działalnością (o czym niżej), przy czym ich skutki mogą dotknąć całą branżę (np. zaostrzenie regulacji wskutek jaskrawego lub uporczywego naruszenia obowiązujących przepisów lub zasad etycznych),

- pracowników, których ze strony podmiotu jako pracodawcy mogą dotknąć różne praktyki dyskryminacyjne, mobbing, molestowanie etc.,

- kontrahentów - w razie nierównego traktowania, zalegania z płatnościami, naruszenia konkurencji poprzez angażowanie jako poddostawców bądź podwykonawców przedsiębiorstwa stosującego nieetyczne praktyki zatrudniania młodocianych, więźniów lub nierespektującego podstawowych praw pracowniczych,

- klientelę lub szerzej interesariuszy, tj. wszystkich, których interes może zostać naruszony wskutek jakiegokolwiek umownego bądź faktycznego kontaktu z produktami lub usługami danej jednostki organizacyjnej.

Rozmiary tego ostatniego kręgu (interesariuszy) mogą być w praktyce nieograniczone. Przykładem tego są masowe delikty gospodarcze - jak wskazuje na to kryzys w branży kredytów hipotecznych subprime w USA, udzielanych z pominięciem elementarnego wymogu zdolności kredytowej, co spowodowało kryzys bankowy, a w konsekwencji ekonomiczny w 2008 r. Poważne skutki, zwłaszcza dla nadzoru giełdowego, ale również dla inwestorów oraz uczestników funduszy emerytalnych, miała afera amerykańskiej spółki giełdowej Enron Corp. Spółka upadła w 2005 r., przy czym skutki upadłości zostały spotęgowane kamuflażem rzeczywistego stanu firmy - trwającymi 
przez lata zabiegami tzw. kreatywnej księgowości - tolerowanym przez audytorów. Upadek Enrona pociągnął za sobą bankructwo lidera branży audytorów Arthur Andersen.

Trudno mierzalne są efekty seryjnych (konstrukcyjnych) deliktów ekologicznych, np. oszustw Volkswagena w oprogramowaniu pomiaru zanieczyszczeń gazów wydechowych silników dieslowskich. Afera ta była w zasadzie klęską wewnętrznego nadzoru compliance. Została wykryta poza firmą, przez zewnętrzny nadzór ekologiczny w Kalifornii. Było to zasługą funkcjonariusza nadzoru, z wykształcenia inżyniera, dysponującego dwudziestoletnim stażem pracy w przemyśle samochodowym. $Z$ racji wykształcenia i doświadczenia zawodowego wyniki testów przeprowadzanych podczas rutynowej kontroli technicznej silników wydały mu się być niemiarodajne. I rzeczywiście, testy przeprowadzane podczas ruchu pojazdów VW z silnikami dieslowskimi wykazały kilkanaście, a nawet kilkadziesiąt razy wyższe wartości zanieczyszczeń. Nikt z wewnątrz przedsiębiorstwa, od pracowników, którzy montowali systemy wydechowe wraz z krytycznym oprogramowaniem, aż po szczebel zarządu, nie ujawnił niczego, ani przed, ani po tym, jak afera została upubliczniona. Jest to poniekąd zrozumiałe, ponieważ sama wiedza o procederze uzasadniałaby zarzut współudziału w oszustwie. Postępowania karne w Niemczech, będące odpryskiem skandalu, ślimaczą się zwłaszcza ze względu na deficyt dowodowy, którego przyczyną jest zmowa milczenia. Konsekwencje finansowe to przede wszystkim nałożone w USA karne odszkodowanie w wysokości 2,8 miliarda USD, która to kwota obejmuje zagregowaną rekompensatę szkód ekologicznych. Powództwa cywilne nabywców krytycznych modeli w USA i Europie stanowią osobną pozycję kosztów, które poniesie firma.

We wskazanych wyżej i innych głośnych aferach kategoria poszkodowanych wykracza poza krąg akcjonariuszy, inwestorów czy nabywców, obejmując w praktyce nieograniczoną liczbę osób dotkniętych skutkami naruszeń prawa i zasad etyki popełnionych w celu maksymalizacji zysku lub osobistych korzyści elity zarządczej firm.

\section{Obszary ryzyka}

Nie jest możliwe przyjęcie jednego, stosowanego powszechnie zakresu znaczeniowego funkcji zapewnienia zgodności działania. Wynika to z analizy przepisów dotyczących kontroli wewnętrznej różnych kategorii podmiotów kontrolowanych (domy maklerskie, towarzystwa funduszy inwestycyjnych, instytucji płatniczej, spółki publicznej). Jest natomiast możliwe i celowe - przynajmniej ze względów praktycznych - wskazanie wspólnych cech charakteryzujących status compliance jako zjawisko coraz powszechniejsze we współczesnym biznesie.

Po raz pierwszy pojęcie compliance w międzynarodowym akcie regulacyjnym pojawiło się w dokumentacji Komitetu Bazylejskiego do spraw Nadzoru Bankowego z 2005 r. określającej funkcję zapewnienia zgodności działania banków. Ryzyko braku zgodności zostało określone jako „ryzyko sankcji prawnych bądź regulaminowych, materialnych strat finansowych lub utraty dobrej reputacji, na jakie narażony jest bank w wyniku niezastosowania się do ustaw, rozporządzeń, przepisów czy przyjętych na siebie standardów i kodeksów postępowania mających zastosowanie do jego działalności." (Komitet Bazylejski ds. Nadzoru Bankowego 2005). W świetle przywołanej definicji zapewnienie zgodności (compliance) można określić jako wszelkie działania ograniczające ryzyko wystąpienia sankcji, strat, utraty reputacji na skutek braku przestrzegania właściwych regulacji. Ryzyko, któremu zapobieżeniu służy właściwie zorganizowany i funkcjonujący system compliance, ujmowane jest w następujące kategorie (Eleryk, Piskorz-Szpytka i Szpytka 2019, 67) :

- ryzyko regulacyjne jako ryzyko nałożenia kar administracyjnych przez organ nadzoru zewnętrznego,

- ryzyko reputacyjne jako ryzyko negatywnego postrzegania danego podmiotu, 
- ryzyko operacyjne jako ryzyko uwikłania się w kosztowne procesy sądowe oraz $\mathrm{w}$ podmiotach nadzorowanych przez regulatora,

- ryzyko negatywnej oceny w trakcie tzw. BION - badania i oceny nadzorczej przyznawanej na podstawie oceny ryzyka podmiotom nadzorowanym przez regulatora jako organ nadzoru nad rynkiem finansowym w Unii Europejskiej; w Polsce proces BION jest realizowany przez Komisję Nadzoru Finansowego (KNF). Negatywna ocenia BION może utrudnić wypłatę dywidendy przez podmiot nadzorowany.

Podstawową funkcją compliance jest zarządzanie ryzykami niezgodności. Zarządzanie ryzykami niezgodności polega na identyfikacji i ocenie ryzyk. Ryzyka te mogą się zmaterializować jako następstwa przyczyn leżących w następujących obszarach:

- zmiana i wprowadzenie nowych regulacji,

- zmiana interpretacji regulacji,

- wprowadzenie nowych produktów i usług w obszarze objętym regulacją,

- naruszenie regulacji w wyniku umyślnego działania,

- naruszenie regulacji wskutek nieznajomości lub błędnej interpretacji przepisów,

- wadliwość regulacji wewnętrznych (lub ich brak), wskutek czego naruszenia powstają u klientów lub kontrahentów.

Chodzi tu w szczególności o zaniechania należytego poinformowania klientów o potencjalnie niebezpiecznych właściwościach produktów bądź usług, względnie zaniechanie właściwej selekcji poddostawców, z punktu widzenia pożądanych praktyk produkcyjnych. Towarzyszą temu często wspomniane wcześniej dwulicowe praktyki biznesu. Finalni producenci markowych produktów przedstawiają siebie jako przestrzegających reżimu czystej produkcji, np. z ekologicznego punktu widzenia (environment friendly), angażując jednocześnie jako poddostawców lub podwykonawców przedsiębiorstwa z „biednego południa”, działające bez żadnych ograniczeń, gdy chodzi o ochronę środowiska i ochronę pracy (np. wysoce toksyczna produkcja - w szczególności proces farbowania - denimu w Bangladeszu przeznaczona dla producentów markowej odzieży z tego materiału). Z prawnego punktu widzenia taki wybór poddostawcy jest legalny, jego działalność z racji braku uregulowań w kraju „brudnej” produkcji nie narusza prawa, ale z punktu widzenia compliance producenta finalnego angażowanie takiego poddostawcy jest naganne i może być sankcjonowane. Podobnie rzecz ma się z lokowaniem produkcji w krajach niskich zarobków. Pozostając przy przykładzie z obszaru produkcji odzieży: jedna sztuka odzieży, za której szwaczka z Bangladeszu otrzymuje 2-4 zł, sprzedawana jest w europejskiej sieci sprzedaży za 200 zł. Tymczasem na Dalekim Wschodzie szyją wszystkie wielkie firmy odzieżowe, polskie też, przyczyniając się do dewastacji środowiska i żerując na braku ochrony pracy, w szczególności w zakresie minimalnego wynagrodzenia i czasu pracy (Solska 2020, 41).

W kontekście powyższych ryzyk compliance stanowi system ochrony przed stratami bezpośrednimi (sankcje regulatorów) i pośrednimi (spadek dochodów wskutek utraty reputacji). Wymusza to systematycznie zwiększająca się liczba regulacji.

Ocena ryzyka powinna być przeprowadzana przez komórkę compliance regularnie i obejmować wszystkie pola aktywności podmiotu, a nawet każdy produkt bądź usługę. Miarą ryzyka regulacyjnego jest dolegliwość konsekwencji naruszenia zgodności, tj. w szczególności wysokość grożących sankcji nakładanych przez regulatora, aż do perspektywy utraty licencji. Przy ocenie ryzyka należy zatem wziąć pod uwagę następujące konsekwencje:

- nałożenie znaczącej kary finansowej lub cofnięcie zezwolenia (licencji) przez regulatora (nadzorcę),

- zagrożenie sankcją karną, 
- upublicznienie informacji o nieprawidłowościach i związana z tym utrata reputacji,

- długotrwały proces sądowy i ryzyko odpowiedzialności odszkodowawczej,

- nałożenie kary przez organ interesów konsumentów.

Na blogu „dla menedżerów” www.langas. pl zawarto przykładową listę zjawisk zagrażających firmie, na które komórka compliance musi zwrócić uwagę. Zjawiska te pojawiają się w dwóch płaszczyznach (Langas.pl 2020):

- wewnątrz organizacji, która to sfera jest przedmiotem regulacji adresowanej do każdego pracownika (np. kodeks etyczny) łącznie $\mathrm{z}$ edukacją w postaci szkoleń uświadamiających konsekwencje działań (decyzji) podejmowanych przez każdego członka załogi,

- na zewnątrz organizacji, w którym to obszarze działają „dobre praktyki” wobec kontrahentów, instytucji ochrony prawnej, co ma na celu ochronę lojalności kontraktowej, danych osobowych, zapobieżenie korupcji i malwersacjom finansowym. Przyporządkowanie zjawisk do płaszczyzn objętych nadzorem compliance jest raczej drugorzędne praktyki korupcyjne mogą się pojawić zarówno w sferze wewnętrznej, jak i zewnętrznej.

Z punktu widzenia obszaru normatywnego, którego przestrzeganie jest monitorowane przez komórkę compliance podmiotu polskiego, a w szczególności polskiej spółki zależnej, naruszenia mogą dotyczyć (Langas. pl 2020):

nieprzestrzegania przepisów FATCA (Foreign Account Tax Compliance Act; umowa między rządem RP a rządem USA w sprawie poprawy wypełniania międzynarodowych obowiązków podatkowych oraz wdrożenia ustawodawstwa FATCA i towarzyszące Uzgodnienia Końcowe, podpisane w Warszawie 7.10.2014 r.; Dz.U. z 2015 r. poz. 1647),

- nieprzestrzegania przepisów CRS (Common Reporting Standard; ustawa z 8.03.2017 r. o wymianie informacji podatkowych z innymi państwami),

- nieposiadania dokumentacji wymaganej z perspektywy regulacji w zakresie zagranicznych spółek kontrolowanych (CFC - Controlled Foreign Company),

- nieprzestrzegania przepisów podatkowych,

- braku weryfikacji kontrahentów w kontekście przepisów o VAT,

- korupcji,

- konfliktu interesów,

- naruszania postanowień ustawy o ochronie danych osobowych,

- uczestniczenia w procederze prania pieniędzy,

- stosowania praktyk ograniczających konkurencję,

- naruszania praw pracowniczych czy praw człowieka,

- nieprzestrzegania norm związanych z ochroną środowiska naturalnego.

\section{Compliance a podatki}

Z zastrzeżeniem, że nie wszystkie wymienione wyżej regulacje mają powszechne zastosowanie - dotyczy to zwłaszcza CRS adresowanych do raportujących instytucji finansowych oraz FATCA przeznaczonej dla raportujących polskich instytucji finansowych (w rozumieniu ustawy z 21.07.2006 r. o nadzorze nad rynkiem finansowym) zwraca uwagę, że pierwszych pięć pozycji w powyższym katalogu dotyczy wykonywania zobowiązań podatkowych. Należyte wykonywanie tych zobowiązań nie budzi wątpliwości i nie wymaga uzasadnień natury etycznej. Społeczna odpowiedzialność biznesu staje się natomiast wyzwaniem w obliczu optymalizacji podatkowej, alokacji istotnych aktywów do rajów podatkowych - procederom służącym $\mathrm{w}$ istocie unikaniu opodatkowania. Praktyki te, rozpowszechnione zwłaszcza wśród wielkich korporacji międzynarodowych, aktualizują problem społecznej odpowiedzialności biznesu. Chodzi o to, jakie oczekiwania społeczne można adresować wobec przedsiębiorstw, których podstawowym celem jest maksymalizacja 
zysku. Czy obok podaży wysokiej jakości dóbr i usług, tworzenia miejsc pracy, powinnością biznesu jest również zaniechanie praktyk optymalizacyjnych opodatkowanie?

$\mathrm{Na}$ to pytanie nie ma jednoznacznej odpowiedzi. Można co najwyżej grupować poglądy nauki między rzeczników (neo)liberalizmu gospodarczego, prospołecznych patriotów oraz zajmujących kompromisowe stanowisko rynkowych realistów (Rok 2015).

Dla neoliberałów optymalizacja podatkowa jest dobrym prawem przedsiębiorcy. Globalna konkurencja wymusza politykę stosowaną przez liderów branż - jeśli najsilniejsi optymalizują swoje zobowiązania podatkowe, to pozostałym nie pozostaje nic innego niż zadbanie o własne koszty, których istotną pozycję stanowią zobowiązania podatkowe. Odmienna polityka prowadziłaby do sprzeniewierzenia się podstawowemu celowi działalności gospodarczej, tj. maksymalizacji zysku, a w konsekwencji do upadku przedsiębiorstwa i zniknięcia z rynku, ze szkodą dla rynku pracy oraz fiskusa.

Przeciwstawny pogląd (społeczno-fiskalny) stoi na gruncie zasady, że podatki powinny być uiszczane w kraju, gdzie prowadzi się działalność przynoszącą dochód. Alokacja aktywów z kraju, gdzie powstały albo są wykorzystywane, przy zastosowaniu instrumentów korporacyjnych prowadzi do nieuzasadnionej premii w postaci eksploatowania lokalnej infrastruktury powstałej ze środków publicznych bez jakiegokolwiek ekwiwalentu, który służyłby jej utrzymaniu i rozwojowi. Interes indywidualny albo grupowy nie może odnosić korzyści ze szkodą dla interesu ogółu rozumianego jako interes kraju, gdzie powstaje przychód.

Rynkowy realizm postrzega optymalizację podatkową jako przeciwwagę fiskalizmu oraz marnotrawienia przychodów podatkowych. Praktyki te obnażają braki legislacyjne reżimu podatkowego. Tak długo, jak działalność gospodarcza w skali globalnej będzie prowadzona w ramach państwowych struktur fiskalnych, tak długo instrumenty fiskalne nie będą w stanie sprostać księgowej alokacji aktywów z krajów wysokich podatków do rajów podatkowych. Społeczna odpowiedzialność biznesu nie wymaga maksymalizowania podatków lecz zysku. Dlatego pytanie, która z firm działających w skali międzynarodowej - w ramach swojej strategii CRS - zobowiąże się do zaniechania praktyk optymalizujących, tj. zmierzających do unikania opodatkowania, długo pozostanie bez odpowiedzi. Wydaje się, że nie można tu liczyć na społeczną odpowiedzialność i zasady etyki. Stanie się to dopiero wtedy, gdy powstaną międzynarodowe instrumenty kontroli fiskalnej, które pozwolą na efektywny monitoring, a w konsekwencji ograniczą lub wyeliminują swobodną alokację obowiązków podatkowych. Opracowana w roku 2017 przez OECD umowa o wymianie informacji bankowej, do której przystąpienie zadeklarowały banki ponad 100 krajów, jest pod tym względem absolutnie niewystarczająca. Obejmuje ona wyłącznie konta osób fizycznych, pozostawiając poza sferą monitorowaną główny środek unikania podatków - spółki offshore w rajach podatkowych.

Kontekst etyczny w sferze podatkowej jest wielowymiarowy i wykracza poza compliance w ścisłym znaczeniu. Niedawny, głośny przypadek unaocznił problem relacji zasad etycznych i tajemnicy bankowej, jak również etycznej oceny odpłatności za pozyskanie informacji relewantnych podatkowo. Specjalista IT, obywatel Niemiec, zatrudniony w szwajcarskim banku, zaoferował niemieckim władzom podatkowym udostępnienie listy klientów banku zamieszkałych w Niemczech i tam podlegających obowiązkowi podatkowemu. Rzecz w tym, że oferta była odpłatna, żądane wynagrodzenie przekraczało $1 \mathrm{mln}$ euro. Po dość długo trwających konsultacjach wewnętrznych niemieckie władze podatkowe zdecydowały się przyjąć ofertę, lista niemieckich klientów banku została przekazana do Niemiec, a informator w zamian za przekazaną listę otrzymał umówione wynagrodzenie (które zgłosił do opodatkowania). Po otrzymaniu listy niemieckie władze skarbowe wszczęły 
niezwłocznie postępowania wyjaśniające na okoliczność nieopodatkowania dochodów (odsetkowych i inwestycyjnych) uzyskanych w Szwajcarii przez niemieckich rezydentów podatkowych figurujących na liście. Negatywne ustalenia prowadziły do wymierzenia zaległych podatków oraz grzywien, których łączna wysokość wyniosła kilkaset milionów euro. Jeszcze przed upublicznieniem tej afery informator został w Szwajcarii aresztowany, oskarżony o wielokrotne złamanie tajemnicy bankowej (ujawnienie kont klientów), skazany na kilkuletnie pozbawienie wolności. Ponieważ sprawa stała się głośna, wywołała ostry konflikt dyplomatyczny między Niemcami a Szwajcarią, wskutek interwencji rządu niemieckiego informator został przedterminowo zwolniony do Niemiec.

Kontrowersje natury etycznej towarzyszą ocenie zachowań większości uczestników przedstawionego przypadku: samego informatora - oferującego odpłatne przekazanie obcej władzy kwalifikowanych informacji, które pozyskał od pracodawcy; władz niemieckich, które przyjęły propozycję naruszającą prawo innego kraju i zapłaciły za nią; wreszcie szwajcarskich organów ścigania chroniących tajemnicy bankowej swojego kraju mimo oczywistych deliktów podatkowych na szkodę obcego fiskusa. Należy tu od razu zastrzec, że zachowanie informatora, żądającego zapłaty za informacje, nie odpowiada temu, co określa się mianem sygnalizacji (whistleblowing - o czym niżej): whistleblower nie działa z pobudek materialnych lecz motywowanych innymi względami, w szczególności dobrem wspólnym narażonym na szwank przez bezprawne lub nieetyczne praktyki.

Powyższy przypadek nie jest najbardziej jaskrawym przykładem konfliktu etycznego w kontekście biznesu międzynarodowego. Przez długi czas tolerowano, a nawet uznawano podatkowo (jako koszt uzyskania przychodu pomniejszający podstawę opodatkowania) wydatki jawnie korupcyjne, ponoszone na rynkach obcych. Praktykę taką tłumaczono zwyczajami lokalnymi oraz powszechnym stosowaniem przez konkurentów. Rezygnacja z tej praktyki i zaniechanie wydatków korupcyjnych mogły przynieść eliminację z rynku. Mimo usztywnienia się władz fiskalnych (odmowa uznawania łapówek za koszt podatkowy) świadczenia korupcyjne są nadal częste, jeśli nie powszechne, w niektórych segmentach produkcji i obrotu (zwłaszcza handlu bronią). Nie tyle biznes jako taki, ile biznes - zwłaszcza międzynarodowy - jest środowiskiem, w którym problemy z etyką są nieuniknione. Natura międzynarodowych stosunków gospodarczych, obok procesów regulacyjnych oraz głośnych przypadków whistleblowingu, stała się przyczyną powstania i rozwoju compliance.

\section{Pozycja nadzoru compliance}

Na pełny system compliance składa się nadzór zewnętrzny sprawowany przez regulatora (np. KNF) oraz nadzór wewnętrzny realizowany przez wyodrębnioną komórkę w ramach struktury wewnętrznej nadzorowanej jednostki organizacyjnej (np. banku, domu maklerskiego). Za kluczowy element systemu compliance uznaje się nadzór wewnętrzny.

W powołanym wyżej dokumencie Komitetu Bazylejskiego do spraw Nadzoru Bankowego sformułowane zostały aktualne do dziś fundamentalne zasady sprawnego funkcjonowania wewnętrznego nadzoru zgodności (compliance), jak następuje (Komitet Bazylejski ds. Nadzoru Bankowego 2005, 7-13):

1. sprawowanie stałego nadzoru nad funkcją compliance przez radę nadzorczą (organ nadzorczy) jednostki, która powinna zatwierdzać politykę compliance; polityka nie powinna ograniczać ani wyłączać jakichkolwiek obszarów działalności i organów jednostki spod nadzoru zgodności (compliance),

2. odpowiedzialność zarządu za efektywność działania komórki compliance,

3. ciążący na zarządzie obowiązek ustanowienia, propagowania i zapewnienia przestrzegania polityki compliance, 
4. ciążący na zarządzie obowiązek ustanowienia stałej, efektywnej komórki compliance,

5. zapewnienie niezależności komórce compliance, przez co należy rozumieć w szczególności bezpośrednią podległość zarządowi oraz swobodne komunikowanie się z organem nadzorczym (radą nadzorczą),

6. zapewnienie komórce compliance zasobów niezbędnych dla efektywnego wykonywania zadań; zasoby te (budżet komórki compliance) powinny być proporcjonalne do poziomu skwantyfikowanego ryzyka braku zgodności,

7. wspieranie zarządu w zapewnieniu zgodności jako podstawowy obowiązek komórki compliance,

8. dokonywanie oceny komórki compliance w ramach funkcjonującego audytu wewnętrznego,

9. przestrzeganie reguł postępowania właściwych dla porządku prawnego, w którym prowadzona jest działalność,

10. ograniczona możliwość outsourcingu w zakresie w wewnętrznego nadzoru nad zgodnością (compliance).

Powyższe „10 przykazań” wyznacza powszechnie akceptowane ramy wewnętrznego nadzoru zgodności (compliance). Jego praktyczne wdrożenie wymaga przedsięwzięcia i wprowadzenia konkretnych rozwiązań w strukturze danej jednostki organizacyjnej, a w szczególności opracowania i wdrożenia procedur nadzoru zgodności, zaangażowania osób zatrudnionych w jednostce do pracy w zakresie compliance, ich stałego szkolenia, zapewnienia wsparcia zarządu i rady nadzorczej jednostki, ustanowienia standardów systematycznego raportowania, budowania świadomości i kultury odpowiedzialności. Nikt nie może znajdować się poza sferą właściwości compliance. Dotyczy to zwłaszcza członków zarządu, ale również rady nadzorczej, na szczeblu której może również dochodzić do praktyk nagannych z punktu widzenia compliance. Potwierdza to skandal sprzed kilku lat w radzie nadzorczej VW. To właśnie odwołany członek rady nadzorczej ujawnił i potrafił poprzeć dowodami w postaci zdjęć, że nominowani przez załogę członkowie rady nadzorczej byli skłaniani do głosowania - w sposób pożądany przez zarząd - fundowanymi przez firmę urlopami w Brazylii, oczywiście all inclusive, co obejmowało również escort service, która w Polsce stanowi przedmiot usług tzw. agencji towarzyskich. Afera ta zintensyfikowała debatę publiczną o potrzebie uregulowania whistleblowingu w ramach wewnętrznej struktury przedsiębiorstw, a ściślej obowiązku skorzystania z tego kanału zgłaszania nieprawidłowości. Nałożenie takiego obowiązku na pracowników i członków organów firmy miało zapobiegać dzikiemu whistleblowingowi, tj. udostępnianiu informacji mediom, co powoduje nieodwracalne szkody wizerunkowe dla firmy. Ostatecznie zrezygnowano z tego obowiązku ze względu na zastrzeżenia ogólniejszej natury - sygnalizacja pozostaje prawem, a nie obowiązkiem pracowników. Rzeczą przedsiębiorstwa jest stworzenie ścieżki i procedur, co samo w sobie stanowi dla załogi zachętę do sygnalizowania naruszeń.

Outsourcing w zakresie wewnętrznego nadzoru compliance, o czym mowa w pkt 10. powyższych zasad, jest zasadniczo dopuszczalny, chyba że wyklucza to konkretny przepis prawa, np. domy maklerskie prawa polskiego nie mogą angażować do tego celu podmiotów zewnętrznych. Zaangażowanie zewnętrznego podmiotu powinno być zawsze poprzedzone due diligence celem sprawdzenia jego kompetencji, sytuacji ekonomicznej oraz posiadania ochrony ubezpieczeniowej (ubezpieczenie OC).

Akcentuje się zasadniczą odmienność i wyraźne rozróżnienie między funkcją nadzoru compliance oraz tradycyjnym doradztwem prawnym, którego celem jest również zapewnienie zgodności działalności danej jednostki z prawem. Doradcy prawni opiniują $\mathrm{z}$ tego punktu widzenia procedury oraz projekty umów, jak również stanowią podstawowe ogniwo w procesach legislacji 
wewnętrznej firmy. Różnice między tymi funkcjami - compliance i doradztwem prawnym - leżą w sferze metody i przedmiotu aktywności. Funkcje compliance ogniskują się wokół procedur, kontroli i audytu, które sprawowane są z punktu widzenia nie tylko prawnych, lecz także pozaprawnych systemów normatywnych (zasady etyki, dobre praktyki). Wymaga to raczej praktycznej znajomości podstawowych obszarów działalności danego podmiotu oraz związanego z nią ryzyka niż kompetencji doradczych. Rozłączność rozumiana jako wyodrębnienie organizacyjne compliance z jednej strony i doradztwa prawnego z drugiej, nie jest kwestionowana w teorii, choć - historycznie - funkcje compliance były lokowane najpierw w strukturach wewnętrznego doradztwa prawnego (biurach prawnych, zespołach radców prawnych) przedsiębiorstw.

Funkcja compliance może być realizowana w rozmaitych modelach organizacyjnych. W modelu scentralizowanym całość zadań skupiona jest w jednej, centralnie usytuowanej, wyspecjalizowanej komórce podlegającej bezpośrednio zarządowi. W modelu rozproszonym zadania compliance realizowane są przez wiele komórek usytuowanych na pośrednich szczeblach zarządzania. Model ten stanowi wyraz kluczowej roli managementu średniego szczebla w promowaniu postaw etycznych. W wielkich firmach kontakt pracowników z zarządem jest sporadyczny. Bezpośrednie zachęty i egzekwowanie przestrzegania zasad pochodzą głównie ze średniego szczebla zarządzania (tone from the middle) (Musiał 2015, 9).

Wydaje się, że optymalny jest hybrydowy model compliance, w którym główne zadania nadzorcze wykonuje wyspecjalizowana komórka wspierana przez ogniwa na średnim szczeblu, gdzie najczęściej wpływają zgłoszenia o nieprawidłowościach i od reakcji na tym szczeblu zależy skuteczność działań naprawczych. Efektywna realizacja funkcji compliance wymaga zaangażowania wszystkich szczebli organizacji. W zaawansowanych systemach zapewnienia zgodności zadania w tym zakresie rozpisane są między zarząd, komórkę compliance oraz wszystkie stanowiska zaangażowane w procesy decyzyjne. Model realizacji zadań compliance jest, albo powinien być, funkcją tzw. trzech linii obrony przed ryzykami zagrażającymi podmiotowi na wszystkich szczeblach organizacji. Pierwszą linię obrony stanowi ogół pracowników, którzy w ramach wykonywanych zadań mają obowiązek przestrzegania prawa i regulacji wewnętrznych. Drugą linię obrony stanowi komórka compliance, która działa wyłącznie w sferze nadzoru nad zgodnością w skali całej organizacji (wdrażanie procedur, kontrola ich przestrzegania, szkolenia), a trzecią linią obrony jest audyt wewnętrzny weryfikujący adekwatność i skuteczność całości systemu nadzoru nad zgodnością (Eleryk, Piskorz-Szpytka i Szpytka 2019, 66).

W prawie polskim przepisy obligujące do wydzielenia w strukturze wewnętrznej komórki nadzoru wewnętrznego i zapewnienia jej niezależności umożliwiającej wykonywanie zadań obowiązują w obszarze podległym nadzorowi (zewnętrznemu) sprawowanemu przez Komisję Nadzoru Finansowego nad podmiotami nadzorowanymi. Obszar ten określa się jako rynek finansowy (w rozumieniu ustawy z 21 lipca 2007 r. o nadzorze nad rynkiem finansowym), który obejmuje następujące segmenty:

- rynek bankowy,

- rynek emerytalny,

- rynek ubezpieczeniowy,

- rynek kapitałowy,

- rynek instytucji płatniczych,

- rynek agencji ratingowych,

- rynek uzupełniający,

- rynek spółdzielczych kas oszczędnościowo-kredytowych oraz

- rynek pośredników kredytu hipotecznego i ich agentów.

Powyższy katalog nie jest wyczerpujący, jako że KNF wykonuje również funkcje nadzorcze wprost na podstawie przepisów prawa europejskiego (np. rozporządzenie BMR Parlamentu Europejskiego i Rady (UE) z 8 czerwca 2016 r. w sprawie indeksów stosowanych jako wskaźniki referencyjne 
w instrumentach finansowych i umowach finansowych lub do pomiarów wyników funduszy inwestycyjnych).

Komórki wewnętrznego nadzoru zgodności stanowią $\mathrm{w}$ istocie instrument realizacji nadzoru zewnętrznego, ponieważ jedną z funkcji compliance w podmiotach nadzorowanych jest czuwanie nad przestrzeganiem zaleceń i decyzji nadzorczych KNF. Sama wewnętrzna komórka compliance może być adresatem oddziaływań nadzoru zewnętrznego, jeśli organ nadzoru stwierdzi nieprawidłowości jej usytuowania w strukturze wewnętrznej podmiotu lub wady w jej funkcjonowaniu. Na tym polega integralny system nadzoru nad rynkiem nadzorowanym przez regulatora (KNF).

Istnienie wydzielonych komórek compliance w strukturze wewnętrznej wprowadzono w 2002 r. jako warunek działalności maklerskiej. W 2009 r. obowiązek ten został rozciągnięty na towarzystwa funduszy inwestycyjnych. Celem było zapewnienie zgodności działalności towarzystwa oraz osób działających na jego rzecz z obowiązującymi przepisami prawa oraz procedurami i regulaminami wewnętrznymi obowiązującymi w towarzystwie.

Krąg nadzorowanych podmiotów podlegających obowiązkom związanym z prowadzeniem działalności na rynku kapitałowym określa ustawa z 29 lipca 2005 r. o nadzorze nad rynkiem kapitałowym. Jest to otwarty katalog kategorii podmiotów działających na rynku kapitałowym. Status prawny tych podmiotów regulują odrębne ustawy. $\mathrm{Na}$ rynku kapitałowym najważniejsze kategorie uczestników to:

- firmy inwestycyjne, w tym domy maklerskie, biura maklerskie banków prowadzących działalność inwestycyjną, a także zagraniczne firmy inwestycyjne,

- emitenci (występujący z ofertą publiczną papierów wartościowych dopuszczonych do obrotu na rynku regulowanym lub ubiegający się o dopuszczenie ich papierów wartościowych do takiego obrotu),
- towarzystwa funduszy inwestycyjnych (TFI).

Sformalizowanie wymogów nadzoru wewnętrznego podmiotów czynnych na rynku finansowym jest domeną branżowych aktów prawnych regulujących poszczególne segmenty tego rynku. Odpowiednie przepisy w tym zakresie zawierają ustawa Prawo bankowe, ustawa o działalności ubezpieczeniowej i reasekuracyjnej, ustawa o obrocie instrumentami finansowymi, ustawa o funduszach inwestycyjnych i zarządzaniu alternatywnymi funduszami inwestycyjnymi oraz ustawa o usługach płatniczych.

\section{Whistleblowing - sygnalizacja}

Zarówno organ nadzoru zewnętrznego, jak i komórki wewnętrznego nadzoru zgodności (compliance) mogą pozyskiwać informację z każdego legalnego źródła, w tym przyjmowania anonimowych zgłoszeń o naruszeniu lub potencjalnym naruszeniu przez dany podmiot przepisów prawa lub zasad etyki w sposób, który angażuje odpowiedzialność podmiotu. Jak wynika z praktyki, szczególnie ważnym źródłem pozyskiwania informacji są zgłoszenia tzw. whistleblowers (sygnalistów, demaskatorów). Wywodzą się oni z reguły, choć nie tylko, z grona pracowników podmiotu i z tego tytułu posiadają wiedzę o okolicznościach naruszenia. Nie są to zatem okoliczności pochodzące $\mathrm{z}$ informacji publicznie dostępnych, lecz ze źródeł wewnętrznych, przy czym zgłaszający powinni poprzeć te okoliczności przekonującymi dowodami bazującymi na wiarygodnych źródłach.

W krajowych przepisach prawa nie istnieje ogólny obowiązek posiadania systemu zgłaszania (przyjmowania) naruszeń przez podmioty prowadzące działalność gospodarczą. Funkcjonowanie mechanizmu bezpiecznego zgłaszania nieprawidłowości stanowi jednak standard kompleksowego zarządzania ryzykiem braku zgodności. Mechanizm ten określa się jako system informowania o nieprawidłowościach (SIN) (Makowicz 2011, 97nn). 
Obowiązek wprowadzenia i utrzymywania systemu ciąży jednak na większości podmiotów z sektora finansów, w szczególności na bankach, towarzystwach funduszy inwestycyjnych oraz domach maklerskich. Zgodnie z ustawą z 1 marca 2018 r. o przeciwdziałaniu prania pieniędzy i finansowania terroryzmu obowiązek wprowadzenia regulacji whistleblowingu ciąży na tzw. instytucjach obowiązanych. Jest to kategoria podmiotów obejmująca również wyżej wskazane banki, domy maklerskie i TFI. Na schemat obligatoryjnego systemu informowania, a ściślej przyjmowania zgłoszeń o nieprawidłowościach i reagowania na takie zgłoszenia, składają się postanowienia dotyczące (Eleryk, Piskorz-Szpytka i Szpytka 2019, 184nn):

- przedmiotu zgłaszanych naruszeń, który obejmuje całą sferę działalności danego podmiotu,

- osoby odpowiedzialnej za przyjmowanie zgłoszeń i właściwej reakcji na takie zgłoszenia - osobą taką powinien być członek zarządu wyznaczony do tego w ramach wewnętrznego podziału kompetencji, względnie rada nadzorcza, gdy zgłoszenie dotyczy członka zarządu; wysoki szczebel, na którym usytuowana jest odpowiedzialność za przyjmowanie zgłoszeń w strukturze podmiotu, odzwierciedla znaczenie, które ustawodawca przywiązuje do procedury whistleblowingu w sektorze finansów,

- sposobu (trybu) składania zgłoszeń, zróżnicowanego w zależności od tego, czy (1) sygnalista pozostaje anonimowy, bądź (2) ujawnia swoją tożsamość jedynie ograniczonemu kręgowi osób, a wobec reszty się nie ujawnia, względnie (3) osoba dokonująca zgłoszenia czyni w to w sposób jawny, ujawniając swoją tożsamość,

- sposobu ochrony zgłaszającego, tak by zapewnić mu co najmniej ochronę przed działaniami o charakterze represyjnym, dyskryminacyjnym lub innymi dolegliwościami; zwłaszcza w odniesieniu do anonimowego zgłaszania naruszeń należy zapewnić sygnaliście ochronę przed ewentualnymi negatywnymi konsekwencjami ze strony przełożonych lub współpracowników w związku z dokonanym zgłoszeniem, w tym ochronę przed dyskryminacją (pominięcie przy awansie lub podwyżce wynagrodzenia), środkami dyscyplinarnymi (np. rozwiązanie umowy o pracę), szykanami, mobbingiem itd.,

- sposobu ochrony danych osobowych sygnalisty oraz osoby, której zarzuca się popełnienie naruszenia; wymóg ochrony danych sygnalisty ma zastosowanie w przypadku, gdy jego tożsamość zostanie ujawniona lub jest możliwa do ujawnienia. Ochronę danych osobowych osoby, której zarzuca się popełnienie naruszenia, uzasadnia się względami zapewnienia poufności, zwłaszcza w przypadku zgłoszeń bezzasadnych, co aktualizuje potrzebę ochrony dóbr osobistych. Środki ochrony danych osobowych powinny odpowiadać przepisom RODO.

Istota regulacji whistleblowingu, tj. zgłaszania i przyjmowania zawiadomień o naruszeniach, zawiera się $\mathrm{w}$ procedurze reagowania na zgłoszenia. Jest to domena komórki nadzoru wewnętrznego (compliance). Działania następcze po przyjęciu zgłoszenia mają na celu jego weryfikację, tj. wyjaśnienie okoliczności, sprawdzenie ich prawdziwości i zasadności. Pozytywna weryfikacja prowadzi do podjęcia kroków wobec sprawcy naruszenia, w szczególności środków dyscyplinarnych, aż do złożenia zawiadomienia organów ścigania o możliwości popełnienia przestępstwa. Powinien temu towarzyszyć odpowiedni instruktaż i akcja informacyjna wobec pracowników. Negatywna weryfikacja pociąga za sobą obowiązki informacyjne wobec zainteresowanych, tj. sygnalisty i osoby obciążonej zarzutem naruszenia.

Cały proces przyjmowania zgłoszenia i czynności następczych powinien przebiegać przy zachowaniu poufności co do tożsamości osób dokonujących zgłoszenia oraz osób, którym zarzuca się dokonanie 
naruszenia. Podmiot, do którego wymóg regulacji procedury whistleblowingu jest adresowany, winien w szczególności ustalić krąg osób mających dostęp do danych dotyczących sygnalisty i osoby, której zarzuca się naruszenia, oraz określić sposób ochrony tych danych. Rygory i ograniczenia mogą zostać rozciągnięte na osoby z zewnątrz, w szczególności pracowników firmy świadczącej usługi IT dla przedsiębiorstwa, w którym nastąpił przypadek zgłoszenia nieprawidłowości.

Wskazane wyżej rozwiązania stanowią przepisane prawem zasady systemu whistleblowingu w sektorze finansów obowiązujące i w niewielkim stopniu zróżnicowane w bankach, biurach maklerskich oraz TFI. Jednocześnie zasady te mogą stanowić wzór do naśladowania dla branż, względnie przedsiębiorstw, w odniesieniu do których brak prawnego obowiązku wdrożenia i utrzymywania systemu nadzoru zgodności (compliance). Z drugiej strony rozmiary i szczególny status tych przedsiębiorstw uzasadniają potrzebę poddania ich nadzorowi compliance. Dotyczy to w szczególności spółek publicznych, którymi - w świetle art. 4 pkt 20 ustawy z 29 lipca 2005 r. o ofercie publicznej i warunkach wprowadzania instrumentów finansowych do zorganizowanego systemu obrotu oraz o spółkach publicznych - są spółki, których przynajmniej jedna akcja jest zdematerializowana w rozumieniu przepisów ustawy o obrocie instrumentami finansowymi.

\section{Compliance a ład korporacyjny}

Spółki publiczne jako takie nie mają obowiązku posiadania systemu nadzoru zgodności, chyba że działają w sferze działalności nadzorowanej przez KNF (o czym niżej). Pewna kategoria spółek publicznych, czyli tzw. spółki giełdowe będące emitentami akcji dopuszczonych do obrotu na rynku kontrolowanym prowadzonym przez Giełdę Papierów Wartościowych (GPW), jest objęta „miękkim”, niezobowiązującym zbiorem zasad ładu korporacyjnego pod nazwą Dobrych Praktyk (Giełda
Papierów Wartościowych 2015). Chociaż Dobre Praktyki nie mają charakteru imperatywnego, spółki giełdowe mają obowiązek poinformowania o zakresie ich przestrzegania. Normują one bowiem ład korporacyjny, a informacja o stosowaniu jego zasad stanowi obligatoryjny element corocznego sprawozdania z działalności spółki giełdowej.

Po myśli Dobrych Praktyk system compliance ma być dostosowany do realiów i otoczenia prawno-ekonomicznego, w którym działa spółka (zasada adekwatności). Kształt organizacyjny nadzoru zgodności nie jest zatem przesądzony. Może (choć nie musi) mieć postać wyodrębnionej komórki compliance. Celem compliance jest nadzór zgodności działalności z prawem, który jest realizowany przez:

- zapewnienie przestrzegania obowiązków,

- zarządzanie ryzykiem braku zgodności,

- doradztwo i pomoc oraz

- raportowanie.

Ten ostatni obowiązek obejmuje raportowanie do nadzorującego członka zarządu, a tym samym do zarządu, jako organu, do rady nadzorczej i komitetu audytu będącego pomocniczym zespołem rady nadzorczej powołanym spośród jej członków. Spółki giełdowe jako jednostki zainteresowania publicznego są obowiązane - na mocy art. 128 ust. 1 ustawy z 11 maja 2017 r. o biegłych rewidentach, firmach audytorskich i nadzorze publicznym - do wyłonienia i utrzymywania komitetu audytu, jako stałego komitetu rady nadzorczej, którego ustawową powinnością jest m.in. monitorowanie skuteczności działania systemów kontroli wewnętrznej. Przez monitorowanie należy rozumieć stałą aktywność obejmującą weryfikację i ocenę sposobu działania systemów i funkcji wewnętrznych. W spółkach, w których istnieje komitet audytu, do rady nadzorczej corocznie wpływają dwa odrębne i niezależne raporty zawierające ocenę funkcjonowania m.in. systemu nadzoru compliance - jeden sporządzony przez zarząd w ramach ogólnych kompetencji zarządczych oraz drugi, sporządzony właśnie przez komitet audytu. 
W odniesieniu do instytucji nadzorowanych przez KNF zasady ładu korporacyjnego (ZŁK) obejmujące nadzór zgodności zyskały sztywniejsze niż Dobre Praktyki podstawy prawne w postaci uchwały KNF nr 218/2014 z 22 lipca 2014 r. obowiązującej od 1 stycznia 2015 r. Instytucje nadzorowane mają obowiązek publicznie dostępnego poinformowania o stosowaniu ZŁK lub o odstąpieniu od stosowania określonych zasad. Odstąpienie od stosowania określonych zasad ma być uzasadnione skalą, charakterem i specyfiką danej instytucji. KNF we wprowadzeniu do ZŁK zawarł katalog podmiotów wyłączonych z obowiązku stosowania tych zasad. Są to mniejsze jednostki wykonujące funkcje pomocnicze lub zlecone przez głównych uczestników rynku finansowego. W odniesieniu do pozostałych jednostek nadzorowanych zasadą pozostaje obowiązek stosowania Z£K w jak najszerszym zakresie, a uzasadnione odstępstwa aktualizują obowiązek informacyjny („comply or explain”), o czym wyżej.

Zasady ładu korporacyjnego, jako wytyczne organu nadzoru, określają relacje wewnętrzne instytucji nadzorowanych, w tym funkcjonowanie wewnętrznego systemu nadzoru zgodnie z działaniami wynikającymi z przepisów prawa i zgodnie z regulacjami wewnętrznymi z uwzględnieniem rekomendacji nadzorczych. Kreując zasady wewnętrznego systemu nadzoru zgodności, ZłK stanowią również podstawę monitorowania i kontroli funkcjonowania tego systemu przez regulatora jako nadzorcę zewnętrznego (KNF). Celem kontroli jest zapewnienie funkcjonowania tego systemu w sposób efektywny, skuteczny i niezależny.

ZŁK nie przesądzają kształtu organizacyjnego sprawowania funkcji wewnętrznego nadzoru zgodności przez jednostkę nadzorowaną. Może to być komórka albo stanowisko jednoosobowe, funkcjonujące w ramach systemu kontroli wewnętrznej albo wyodrębnione jako komórka nadzoru zgodności (compliance). Agenda ta może pozostawać w ramach struktury wewnętrznej jednostki albo być zlecona podmiotowi zewnętrznemu. Akcent jest położony na zapewnienie bezpośredniego komunikowania się z zarządem, radą nadzorczą i/lub komitetem audytu, bezpośredniego raportowania do tych organów, łącznie z prawem uczestniczenia w ich posiedzeniach poświęconych sprawom kontroli i nadzoru zgodności.

Wewnętrzny nadzór zgodności jako element ZŁK zyskuje dodatkowy obszar właściwości. Zgodność monitorowana przez nadzór compliance obejmuje również sferę stosowania ZŁK. Innymi słowy, zakres nadzoru nad zgodnością rozciąga się na same zasady ładu korporacyjnego. W konsekwencji dla systemu compliance powstaje dodatkowy obowiązek weryfikacji za pomocą dostępnych środków (np. kontroli wewnętrznej), czy obowiązki wynikające z ZŁK są wykonywane. Stanowi to również przedmiot nadzoru zewnętrznego KNF z konsekwencjami przewidzianymi na wypadek naruszenia zasad prawidłowego funkcjonowania rynku finansowego, których ochronie służą ZŁK. Innymi słowy nadzór zewnętrzny nad przestrzeganiem ZŁK rozciąga się również na funkcjonowanie wewnętrznego nadzoru zgodności (compliance) w tym zakresie.

\section{Bibliografia}

Eleryk, Paweł, Alicja Piskorz-Szpytka, i Przemysław Szpytka. 2019. Compliance w podmiotach nadzorowanych rynku finansowego. Aspekty praktyczne. Warszawa: Wolters Kluwer Polska.

Giełda Papierów Wartościowych. 2015. Dobre Praktyki spótek notowanych na GPW 2016. Warszawa: Giełda Papierów Wartościowych. Dostęp 31.03.2020. https://www.gpw.pl/pub/GPW/files/ PDF/GPW_1015_17_DOBRE_PRAKTYKI_v2.pdf.

Komitet Bazylejski ds. Nadzoru Bankowego. 2005. Zgodność i funkcja zapewnienia zgodności w bankach. Dostęp 31.03.2020. https://www.knf.gov.pl/ knf/pl/komponenty/img/Zgodnosc\%20i\%20 funkcja\%20zapewnienia\%20zgodnosci\%20w\%20 bankach.pdf.

Langas.pl. 2020. Blog. Dostęp 12.01.2020. http:// www.langas.pl/blog.

Makowicz, Bartosz. 2011. Compliance w przedsiębiorstwie. Warszawa: Wolters Kluwer Polska. 
Musiał, Marcin. 2015. „Jaki kodeks?” W Etyka i compliance w organizacji. Przeglad Zagadnień, red. Agnieszka Abec, 7-9. Warszawa: Forum Odpowiedzialnego Biznesu. Dostęp 31.03.2020. http:// docplayer.pl/6724221-Etyka-i-compliance-w-organizacji.html.

Rok, Bolesław. 2015. „Czy społeczna odpowiedzialność ma coś wspólnego z płaceniem podatków?" W Etyka i compliance w organizacji. Przeglad
Zagadnień, red. Agnieszka Abec, 10-11. Warszawa: Forum Odpowiedzialnego Biznesu. Dostęp 31.03.2020. http://docplayer.pl/6724221-Etyka-i-compliance-w-organizacji.html.

Solska, Joanna. 2020. „Czyszczenie szaf.” Polityka, January 14, 2020. www.polityka.pl/tygodnikpolityka/rynek/1938230,1,dochody-z-ekomody.read. 